\title{
Thermal, Spectroscopic and Chemical Characterization of Biofield Energy Treated Anisole
}

\author{
Mahendra Kumar Trivedi ${ }^{1}$, Alice Branton ${ }^{1}$, Dahryn Trivedi ${ }^{1}$, Gopal Nayak ${ }^{1}$, Gunin Saikia ${ }^{2}$ and Snehasis Jana ${ }^{2 *}$ \\ ${ }^{1}$ Trivedi Global Inc., 10624 S Eastern Avenue Suite A-969, Henderson, NV 89052, USA \\ ${ }^{2}$ Trivedi Science Research Laboratory Pvt. Ltd., Bhopal, Madhya Pradesh, India
}

\begin{abstract}
The objective of the present study was to evaluate the impact of biofield energy treatment on the thermal, spectroscopic, and chemical properties of anisole by various analytical methods such as gas chromatography-mass spectrometry (GC-MS), high performance liquid chromatography (HPLC), differential scanning calorimetry (DSC), Fourier transform infrared (FT-IR) spectroscopy, and ultraviolet-visible (UV-Vis) spectroscopy. The anisole sample was divided into two parts, control and treated. The control part was remained same while the other part was treated with Mr. Trivedi's unique biofield energy treatment. Mass spectra showed the molecular ion peak with five fragmented peaks in control and all treated samples. The isotopic abundance ratio of ${ }^{2} \mathrm{H} /{ }^{1} \mathrm{H}$, and ${ }^{13} \mathrm{C} /{ }^{12} \mathrm{C}[(\mathrm{PM}+1) / \mathrm{PM}]$ in treated sample was increased by $154.47 \%$ (T1) as compared to the control [where, PM- primary molecule, (PM+1)-isotopic molecule either for ${ }^{13} \mathrm{C}$ or ${ }^{2} \mathrm{H}$ ]. The HPLC chromatogram showed retention time of treated anisole was slightly decreased as compared to the control. Moreover, the heat change in the sharp endothermic transition of treated anisole was increased by $389.07 \%$ in DSC thermogram as compared to the control. Further, C-C aromatic stretching frequency of treated sample was shifted by $2 \mathrm{~cm}^{-1}$ to low energy region in FT-IR spectroscopy. The UV-Vis spectra of control sample showed characteristic absorption peaks at $325 \mathrm{~nm}$, which was red shifted and appeared as shoulder in the treated sample. These results suggested that biofield treatment has significantly altered the physical and spectroscopic properties of anisole, which could make them stable solvent for organic synthesis and as a suitable reaction intermediate in industrial applications.
\end{abstract}

Keywords: Biofield energy treatment; Anisole; Gas chromatographyMass spectrometry; High performance liquid chromatography

Abbreviations: GC-MS: Gas chromatography-Mass spectrometry; PM: Primary molecule; $\mathrm{PM}+1$ : Isotopic molecule either for ${ }^{13} \mathrm{C} /{ }^{12} \mathrm{C}$ or ${ }^{2} \mathrm{H} /{ }^{1} \mathrm{H}$

\section{Introduction}

Anisole, phenyl ether (Ph-O-Me, Figure 1) usually used as a starting material for various pharmaceutical/flavonoid products and as solvent in organic synthesis and physical studies [1]. It is used for the synthesis of raw material for drugs such as cyclofenil, in treating Raynaud's phenomenon in people with scleroderma [2], and tramadol hydrochloride, that is used for the relief of moderate or severe pain [3]. 4-hydroxyanisole and t-butylhydroxyanisole are the most popular derivatives of anisole and used extensively as depigmenting agents and antioxidant respectively $[4,5]$. The anisole was used selectively in various steps as a solvent in the synthesis of cefoxitin [6] and latamoxef an antibiotic administered intravenously has a broad spectrum of activity against Gram-positive and Gram-negative bacteria [7]. Anisole is a weakly polar aprotic solvent with lower electric permittivity $(\varepsilon s=4.33)$, which allows its usability in cyclic voltammetric studies as an alternative to tetrahydrofuran and dichloromethane [8]. The use of hazardous and toxic solvents in synthesis and characterization is regarded as a very important point for the safety of lab-workers and pollution. Nowadays, a relatively green solvent, anisole, have been successfully applied to process organic/polymer solar cells [9]. Hence, the stability of anisole is important to perform organic reactions at moderate temperature, and its applicability in pharmaceutical products. The chemical and physical property could be altered by Mr. Trivedi's unique biofield energy treatment which is well known to modify the physical, and structural characteristics of living and non-living substances $[10,11]$. The electrical current generates through internal physiological processes like blood flow, brain activity, and heart function etc. exists inside the human body in the form of vibratory energy particles like ions, protons, and electrons and they generate magnetic field in the human body [12] The energy fields that purportedly surround the human body is called the biofield. Currently, researchers have been exploring the potential benefits of integrative energy medicine in a variety of situations to promote overall health and wellness of individuals. The energy medicine is regarded as one of the complementary and alternative medicine (CAM) and defined under the subcategory of energy therapies by National Center for Complementary and Alternative Medicine (NCCAM) [13]. The practitioner of energy medicine can harness the energy from the environment/universe and can transmit into any object around the globe. The object(s) receive the biofield energy and responded in a useful way. This process is called as biofield energy treatment. Mr. Trivedi's unique biofield treatment is also called as The Trivedi Effect ${ }^{\circledR}$. The Trivedi Effect ${ }^{\circledR}$ has been well studied in various research fields like microbiology $[10,14]$ biotechnology $[15,16]$ and agricultural research [17]. Based on the outstanding results achieved by biofield treatment on microbiology and biotechnology, an attempt was made to evaluate the impact of biofield treatment on various properties of anisole.

*Corresponding author: Snehasis Jana, Trivedi Science Research Laboratory Pvt. Ltd., Hall-A, Chinar Mega Mall, Chinar Fortune City, Hoshangabad Rd., Bhopal-462 026, Madhya Pradesh, India, Tel: +91-755-6660006; E-mail: publication@trivedisrl.com

Received: October 06, 2015; Accepted: October 14, 2015; Published: October 21, 2015

Citation: Trivedi MK, Branton A, Trivedi D, Nayak G, Saikia G, et al. (2015) Thermal, Spectroscopic and Chemical Characterization of Biofield Energy Treated Anisole. Organic Chem Curr Res 4:152. doi:10.4172/2161-0401.1000152

Copyright: ( 2015 Trivedi MK, et al. This is an open-access article distributed under the terms of the Creative Commons Attribution License, which permits unrestricted use, distribution, and reproduction in any medium, provided the original author and source are credited. 
<smiles>COc1ccccc1</smiles>

Anisole

Figure 1: Structure of anisole.

\section{Experimental}

\section{Materials and methods}

Anisole was procured from Genuine Chemical, India. The samples were characterized using, gas chromatography-mass spectrometry (GC-MS), high performance liquid chromatography (HPLC), differential scanning calorimetry (DSC), Fourier transform infrared (FT-IR) spectroscopy, and ultraviolet-visible (UV-Vis) spectroscopy.

\section{Biofield treatment modalities}

Anisole was taken in this experiment for biofield treatment. The compound was divided into two parts named as control and treated. No treatment was given to the control set. The second set of anisole was handed over to Mr. Trivedi for biofield energy treatment under laboratory conditions. Mr. Trivedi provided the biofield treatment through his energy transmission process to second sets of samples without touching. After treatment, the treated samples were stored at standard conditions for GC-MS analysis as per the standard protocol. The experimental results in treated groups were analyzed and compared with the untreated (control) set.

\section{GC-MS}

The GC-MS analysis was done on Perkin Elmer/auto system XL built with Turbo mass, USA. The detection limit of the detector is upto 1 picogram. For GC-MS analysis, the treated sample was further divided into three parts as T1, T2, and T3. The GC-MS spectrum was plotted as the $\%$ abundance vs. mass to charge ratio $(\mathrm{m} / \mathrm{z})$. The isotopic abundance ratio of ${ }^{13} \mathrm{C} /{ }^{12} \mathrm{C}$ or ${ }^{2} \mathrm{H} /{ }^{1} \mathrm{H},(\mathrm{PM}+1) / \mathrm{PM}$, and ${ }^{18} \mathrm{O} /{ }^{16} \mathrm{O},(\mathrm{PM}+2) /$ $\mathrm{PM}$ was expressed by its deviation in the treated sample as compared to the control. The percentage changes in isotopic ratio $(\mathrm{PM}+1) / \mathrm{PM}$ and $(\mathrm{PM}+2) / \mathrm{PM}$ was calculated on a percentage scale from the following formula:

$$
\text { Percentage changes in isotopic ratio }(P M+1 / P M)=\frac{R_{\text {Treated }}-R_{\text {Control }}}{R_{\text {Control }}} \times 100
$$

Where, $\mathrm{R}_{\text {Treated }}$ and $\mathrm{R}_{\text {Control }}$ are the ratios of intensity at $(\mathrm{PM}+1)$ to $\mathrm{PM}$ in mass spectra of treated and control samples respectively.

\section{HPLC}

The HPLC analysis was performed on a Knauer High Performance Liquid Chromatograph (Berlin, Germany), equipped with Smartline Pump 1000 and a UV 2600 detector. Chromatographic separation was performed on a $\mathrm{C}_{18}$ column (Eurospher 100) with a dimension of 250 $\times 4 \mathrm{~mm}$ and $5 \mu \mathrm{m}$ particle size. The mobile phase used was methanol with a flow rate of $1 \mathrm{~mL} / \mathrm{min}$ at $25^{\circ} \mathrm{C}$. The solutions of standard and the sample were prepared in methanol for both GC-MS and HPLC studies.
The method development for this assay of anisole based on its chemical properties. Anisole is polar molecule and therefore, a polar solvent methanol was used as the diluent.

\section{DSC}

The DSC was done with Perkin Elmer/Pyris-1, USA, a heating rate of $10^{\circ} \mathrm{C} / \mathrm{min}$ and nitrogen flow of $5 \mathrm{~mL} / \mathrm{min}$ was used. The change in latent heat $(\Delta \mathrm{H})$ of control and treated ethanol was recorded from their respective DSC curves. The percent change in boiling point and latent heat of vaporization was computed using following equations: Percent change was calculated using following equations:

$$
\% \text { change }=\frac{\left[\mathrm{T}_{\text {Treated }}-\mathrm{T}_{\text {Control }}\right]}{\mathrm{T}_{\text {Control }}} \times 100
$$

Where, $\mathrm{T}_{\text {Control }}$ and $\mathrm{T}_{\text {Treated }}$ are the peak point of degradation control and treated samples, respectively.

\section{FT-IR spectroscopy}

For FT-IR spectra, Shimadzu's Fourier transform infrared spectrometer (Japan) was used in the frequency region of 500-4000 $\mathrm{cm}^{-1}$. The samples were prepared by crushing anisole crystals with spectroscopic grade $\mathrm{KBr}$ into fine powder and then pressed into pellets.

\section{UV-Vis spectroscopy}

UV-Vis spectra of control and treated samples of anisole were acquired from Shimadzu UV-2400 PC series spectrophotometer within the wavelength region of 200-400 $\mathrm{nm}$. Quartz cell with $1 \mathrm{~cm}$ and a slit width of $2.0 \mathrm{~nm}$ were used for analysis.

\section{Results and Discussion}

\section{GC-MS analysis}

The GC-MS spectra of control and treated samples of anisole are presented in Figure 2. For GC-MS study of the treated sample was divided into three parts T1, T2, and T3. Mass spectra showed the PM peak at $m / z=108$ in control and all the treated anisole samples (T1, $\mathrm{T} 2$, and $\mathrm{T} 3)$ same intensities. The intensity ratio of $(\mathrm{PM}+1) / \mathrm{PM}$ is presented in Table 1 and percent change in isotopic abundance ratio was calculated and shown in Figure 3. Five major peaks at $m / z=108$, $93,78,65,51$, and 39 were observed in both control and treated samples of anisole due to the following ions respectively: $\mathrm{C}_{7} \mathrm{H}_{8} \mathrm{O}^{+}$, $\mathrm{C}_{6} \mathrm{H}_{5} \mathrm{O}^{+}, \mathrm{C}_{6} \mathrm{H}_{6}{ }^{+}, \mathrm{C}_{5} \mathrm{H}_{5}{ }^{+}, \mathrm{C}_{4} \mathrm{H}_{3}{ }^{+}$, and $\mathrm{C}_{3} \mathrm{H}_{3}{ }^{+}$ions. Peaks at $m / z=93,78$, 65,51 , and 39 were observed due to the fragmentation of anisole to phenol, benzene, cyclopentadiene, buten-3-yne and propyne ions. All peaks were same for both treated and control samples and well matched with reported literature [18]. The isotopic abundance ratio of $(\mathrm{PM}+1) / \mathrm{PM}$ of anisole sample was increased in all the treated samples $\mathrm{T} 1=154.47 \%, \mathrm{~T} 2=21.71 \%$, and $\mathrm{T} 3=34.44 \%$. However, the isotopic abundance ratio of $(\mathrm{PM}+2) / \mathrm{PM}$ was not seen in the mass spectrum. The increased isotopic abundance ratio of $(\mathrm{PM}+1) / \mathrm{PM}$ in the treated anisole may increase the effective mass $(\mu)$ and binding energy in this molecules with heavier isotopes. This may alter the property of the chemical bond and eventually property of the molecule. The transformation may be happened in nuclear level due to the biofield energy treatment. It is expected that some of ${ }^{1} \mathrm{H}$ and ${ }^{12} \mathrm{C}$ may be interconverted to ${ }^{2} \mathrm{H}$, and ${ }^{13} \mathrm{C}$ atoms inside the molecule, respectively. The bond strength also plays an important role in kinetic effects due to the greater strength of the isotopic bonds such as ${ }^{2} \mathrm{H}-{ }^{12} \mathrm{C}$ bond relative to a ${ }^{1} \mathrm{H}_{-}{ }^{12} \mathrm{C}$ bond [19]. 

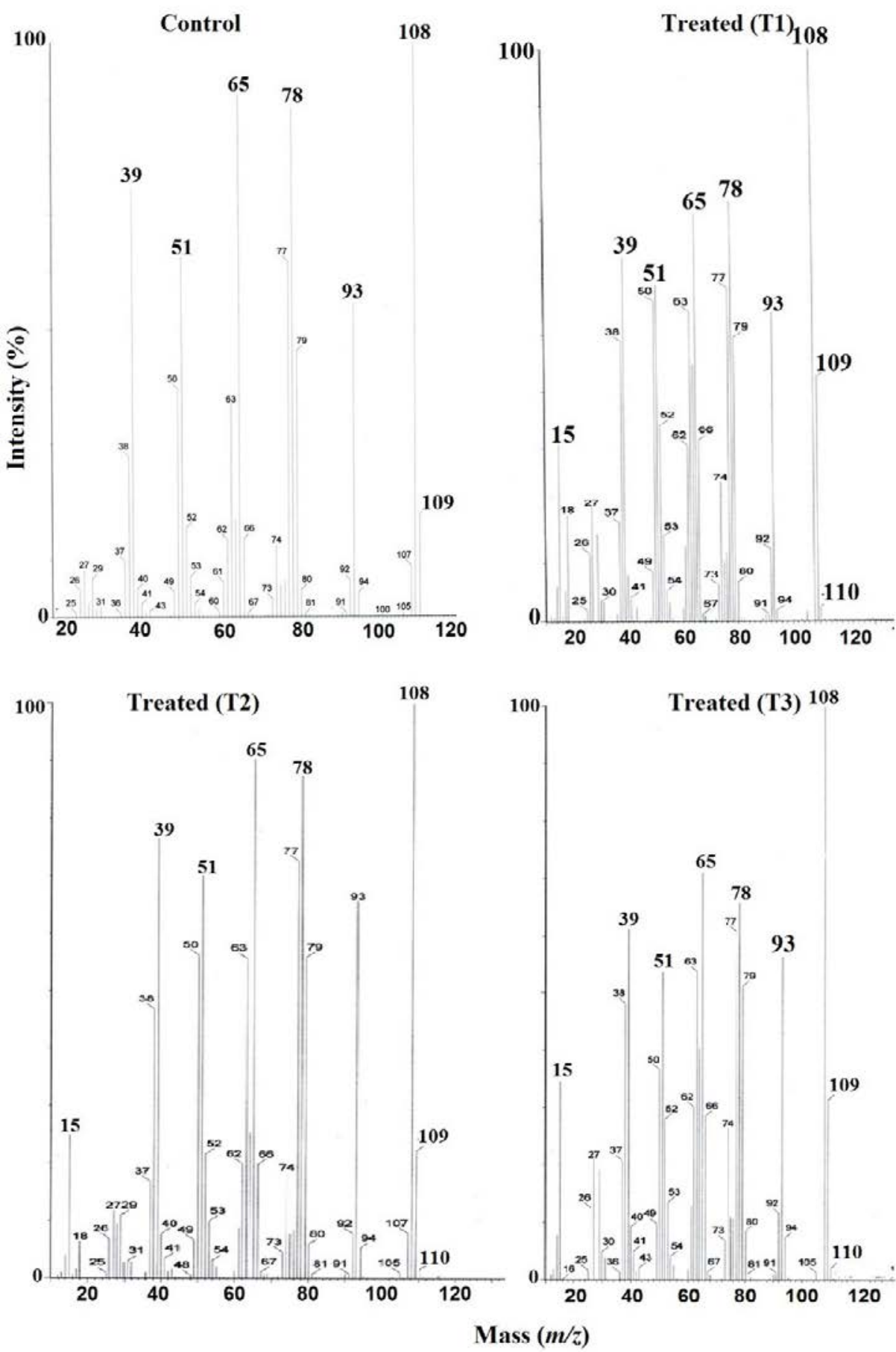

Figure 2: GC-MS spectra of control and treated anisole samples.

\begin{tabular}{|c|c|c|c|c|}
\hline \multirow{2}{*}{ Peak Intensity } & \multirow{2}{*}{ Control } & \multicolumn{3}{|c|}{ Treated } \\
\cline { 3 - 5 } & & T1 & T2 & T3 \\
\hline$m / z=(P M)$ & 100 & 100.00 & 82.62 & 98.19 \\
\hline$m / z=(P M+1)$ & 23.11 & 23.76 & 13.00 & 20.25 \\
\hline$m / z=(P M+2)$ & 1.05 & 2.05 & 1.00 & 1.80 \\
\hline
\end{tabular}

Table 1: GC-MS isotopic abundance analysis result of anisole.

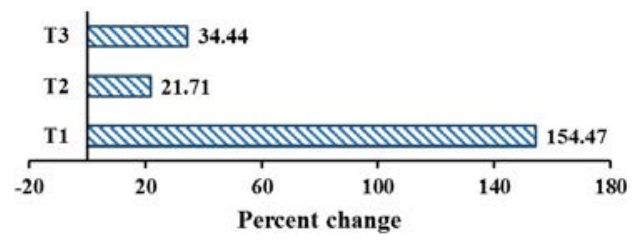

Figure 3: Percent change in isotopic abundance $(\mathrm{PM}+1) / \mathrm{PM}$ and $(\mathrm{PM}+2) / \mathrm{PM}$ of anisole under biofield treatment as compared to control. 


\section{HPLC analysis}

HPLC chromatogram is the detector response as a function of time is shown in Figure 4 (control and treated anisole). The compounds have been separated into two peaks in both control and treated samples. The retention time $\left(\mathrm{T}_{\mathrm{R}}\right)$ of control sample was $2.58 \mathrm{~min}$ and $2.96 \mathrm{~min}$ with relative intensity $22.51 \%$ and $77.49 \%$, respectively and the $\mathrm{T}_{\mathrm{R}}$ of treated anisole showed at $2.41 \mathrm{~min}$ and $2.71 \mathrm{~min}$ with relative intensity $29.85 \%$ and $70.10 \%$, respectively. These decreased in $\mathrm{T}_{\mathrm{R}}$ may be attributed to the increased polarity of anisole after biofield energy treatment.

\section{DSC analysis}

DSC was used for thermal analysis of control and treated anisole samples. The change in heat $(\Delta \mathrm{H})$ of control and treated samples is shown in Figure 5. One strong endothermic transition was observed at $114.09^{\circ} \mathrm{C}$ in control anisole sample. However, it was observed at $112.27^{\circ} \mathrm{C}$ after biofield energy treatment. The heat absorbed in this process was found to be $550.35 \mathrm{~J} / \mathrm{g}$ in treated anisole sample. The increase in $\Delta \mathrm{H}$ in the treated sample was significantly increased by $389.08 \%$ as compared to the control, (Table 2). The increase in $\Delta \mathrm{H}$ after biofield treatment could be due to alteration of intermolecular interaction in anisole that might increase the thermal stability of the treated samples.

\section{FT-IR spectroscopic analysis}

The FT-IR spectrum of control and biofield energy treated anisole is shown in Figure 6. The vibrational peaks at $3003 \mathrm{~cm}^{-1}$ and 2955 $\mathrm{cm}^{-1}$ were assigned to aromatic $\mathrm{C}-\mathrm{H}$ stretching of the phenyl ring for both control and treated samples. The vibrational peak at $2904 \mathrm{~cm}^{-1}$ was observed due to the methyl (aliphatic) $\mathrm{C}-\mathrm{H}$ stretching for both the control and treated samples. The $\mathrm{C}-\mathrm{C}$ stretching frequency (inring, aromatic) was observed at $1603 \mathrm{~cm}^{-1}$ and $1496 \mathrm{~cm}^{-1}$ for control sample whereas it was shifted to $1601 \mathrm{~cm}^{-1}$ and $1494 \mathrm{~cm}^{-1}$ (the lower energy region) after biofield energy treatment. The characteristic C-O stretching for ethers was seen at $1302 \mathrm{~cm}^{-1}$ and $1077 \mathrm{~cm}^{-1}$ for aliphatic (R-O) and aromatic (Ar-O) parts respectively in both control and treated samples. The shifting of aromatic stretching frequency to the lower wavenumber may be attributed to the increased number of higher isotopes $(\mathrm{PM}+1)$ after biofield energy treatment. The vibration energy of a bond (in wavenumbers) in a molecule is represented by the following equation

$$
\bar{v}=\frac{1}{2 \pi \mathrm{C}} \sqrt{\frac{\mathrm{K}}{\mu}}
$$

Where, $K$ is a constant that varies from one bond to another, $\mathrm{C}$ is the speed of light, and $\mu=\mathrm{m}_{1} \mathrm{~m}_{2} /\left(\mathrm{m}_{1}+\mathrm{m}_{2}\right)$, is the reduced mass or effective mass ( $m_{i}$ is the mass of atom $i$ ). According to the equation (1), $\bar{v}$ is inversely proportional to the reduced mass [20]. It exhibited that reduced mass is higher in case of heavier isotope as compared to lighter one. This showed that anisole with heavier isotope after biofield energy treatment has low vibration energy as compared to lighter in control. Due to the increased isotopic abundance ratio of $(\mathrm{PM}+1)$ in the treated anisole, the effective mass $(\mu)$ was increased and subsequently wavenumber was decreased. The FT-IR results after biofield energy treatment as compared to the control have shown changes in chemical properties of the molecule, which may lead to the changes in polarity as well as thermal property of anisole molecule.

\section{UV-Vis spectroscopic analysis}

The UV-vis spectra of anisole in methanol are shown in Figure 7. The UV spectrum of control sample showed characteristic absorption peaks at $\lambda_{\max }=325 \mathrm{~nm}$, however after biofield treatment the peak was red shifted and exhibited a shoulder. Both the control and treated samples showed characteristic strong absorption in the range of 200$275 \mathrm{~nm}$, which was saturated at that particular concentration. Reported
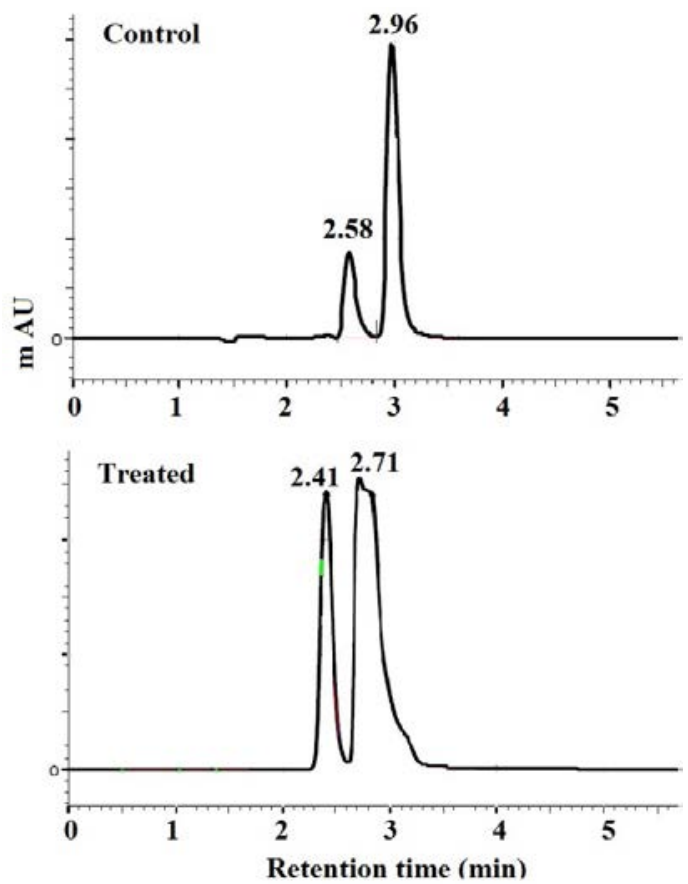

Figure 4: HPLC chromatograms of control and treated anisole.

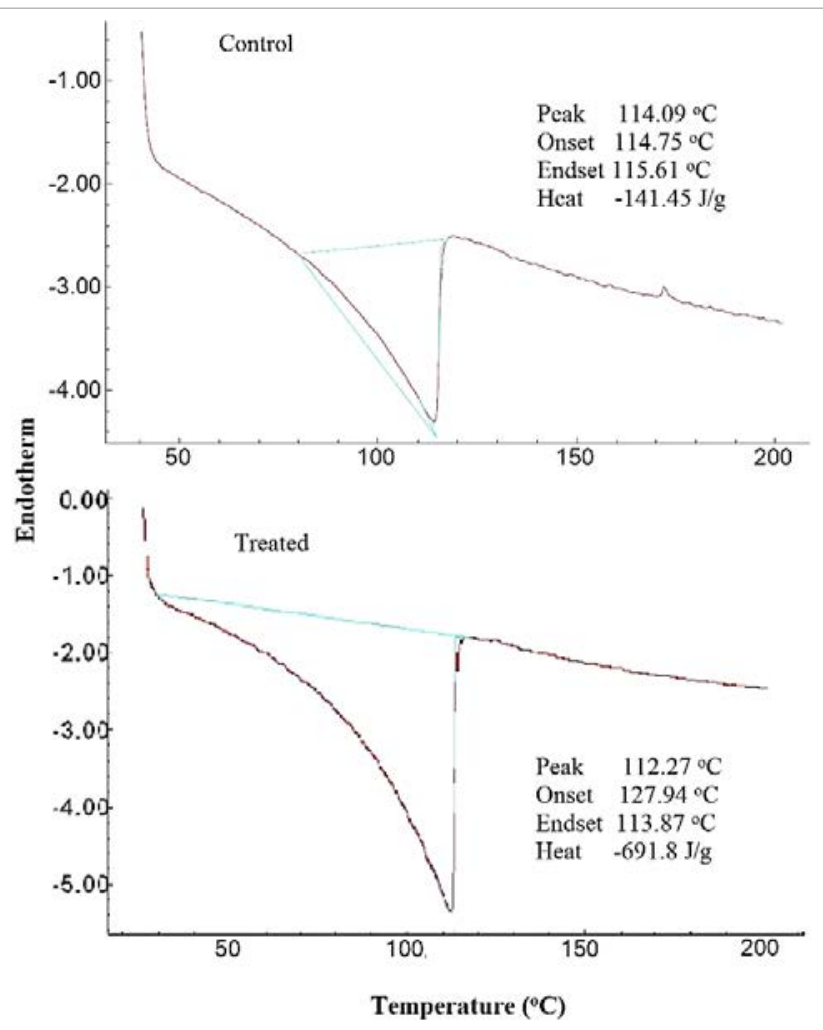

Figure 5: DSC of control and treated anisole. 
Citation: Trivedi MK, Branton A, Trivedi D, Nayak G, Saikia G, et al. (2015) Thermal, Spectroscopic and Chemical Characterization of Biofield Energy Treated Anisole. Organic Chem Curr Res 4:152. doi:10.4172/2161-0401.1000152

Page 5 of 6

\begin{tabular}{|c|c|c|}
\hline & Peak position $\left.\mathbf{~}^{\circ} \mathbf{C}\right)$ & Heat change $\mathbf{~} / \mathbf{g}$ \\
\hline Control & 114.09 & -141.45 \\
\hline Treated & 112.27 & -691.80 \\
\hline Percent Change & -1.59 & 389.07 \\
\hline
\end{tabular}

Table 2: DSC analysis of anisole.

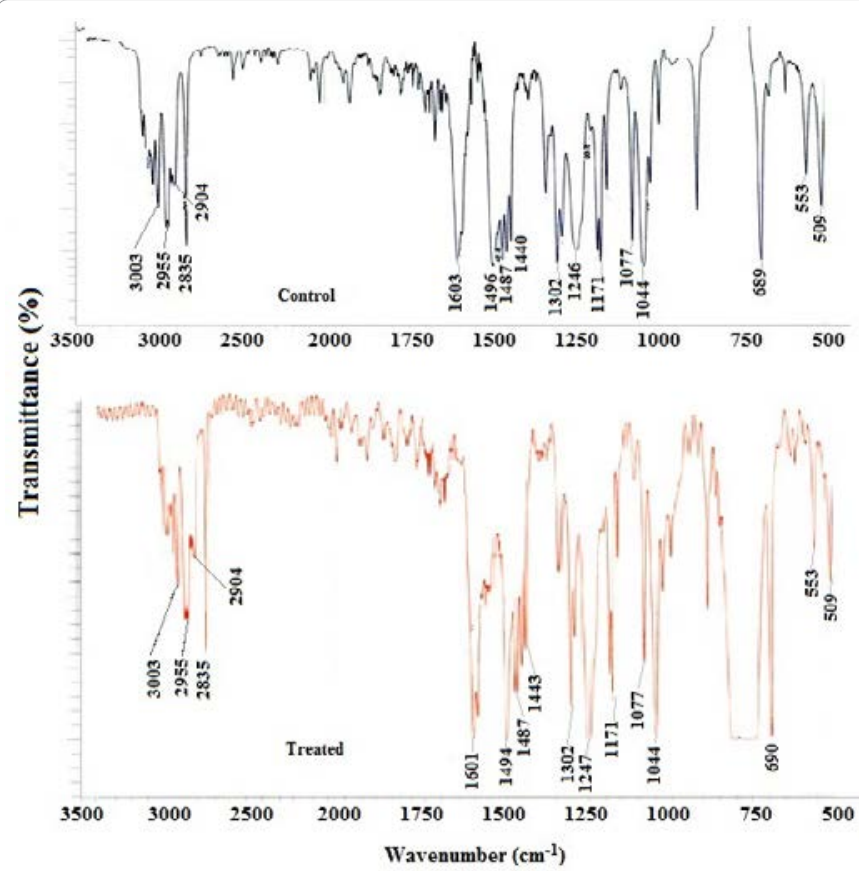

Figure 6: FT-IR spectra of control and treated anisole.

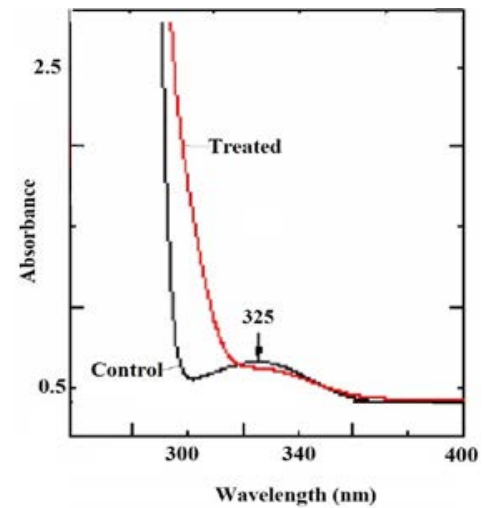

Figure 7: UV-Vis spectra of control and treated samples of anisole.

literature have suggested that the first strong band in the region of 300-350 $\mathrm{nm}$ that corresponds to $\pi-\pi^{*}$ transitions and the weak $\mathrm{n}-\pi^{*}$ band in the region of 320-370 $\mathrm{nm}$ [21]. The $\mathrm{n}-\pi^{*}$ bands show a distinct shift in the treated sample, it was observed with the varied polarity of the medium/solvent and reported in the literature [22]. Hence, it is hypothesized that biofield treatment might induce some polarity to the system that makes shift of the absorption positions. This observation is also supported by the lower $T_{R}$ of the treated sample in HPLC chromatogram.

\section{Conclusions}

Anisole was studied to see the influence of biofield energy treatment and isotopic abundance ratio of treated anisole was compared with the control sample. After performing various analytical studies on biofield treated anisole, it was found that anisole has shown a strong response to biofield energy treatment. GC-MS data showed the isotopic abundance ratio of $(\mathrm{PM}+1) / \mathrm{PM}$ was increased by $154.47 \%$ in the treated sample as compared to the control. Biofield energy may also alter the polarity of the molecule, which eventually alters the absorption position in UV-Vis and the retention time peak in HPLC chromatogram. Higher isotopic ratio $(\mathrm{PM}+1) / \mathrm{PM}$ in treated samples correlated with the higher $\Delta \mathrm{H}$ in DSC thermogram and shifting of aromatic $\mathrm{C}-\mathrm{C}$ stretching frequency in FT-IR spectra to the lower wavenumber region as compared to the untreated sample. It is assumed that biofield energy treatment may enhance the stability of the organic small molecule of industrial importance, which ultimately affects the shelf-life and efficacy of the final product.

\section{Acknowledgment}

The authors would like to acknowledge the whole team of Sophisticated Analytical Instrument Facility (SAIF), Nagpur for providing the instrumental facility. We are very grateful for the support of Trivedi Science, Trivedi Master Wellness and Trivedi Testimonials in this research work.

\section{References}

1. Ullmann (2002) Encyclopedia of industrial chemistry, Wiley-VCH Verlag, New York.

2. Torres MA, Furst DE (1990) Treatment of generalized systemic sclerosis Rheum Dis Clin North Am 16: 217-241.

3. Katz WA (1996) Pharmacology and clinical experience with tramadol in osteoarthritis. Drugs 52 Suppl 3: 39-47.

4. Fleischer AB Jr, Schwartzel EH, Colby SI, Altman DJ (2000) The combination of $2 \%$ 4-hydroxyanisole (Mequinol) and $0.01 \%$ tretinoin is effective in improving the appearance of solar lentigines and related hyperpigmented lesions in two double-blind multicenter clinical studies. J Am Acad Dermatol 42: 459-467.

5. Sasikumar JM, Mathew GM, Priya Darsini DT (2010) Comparative studies on antioxidant activity of methanol extract and flavonoid fraction of Nyctanthes arbortristis leaves. EJEAF Che 9: 227-233.

6. Zimmerman SB, Stapley EO (1976) Relative morphological effects induced by cefoxitin and other beta-lactam antibiotics in vitro. Antimicrob Agents Chemother 9: 318-326.

7. Carmine AA, Brogden RN, Heel RC, Romankiewicz JA, Speight TM, et al. (1983) Moxalactam (latamoxef). A review of its antibacterial activity, pharmacokinetic properties and therapeutic use. Drugs 26: 279-333.

8. Jan SJ, Cembor M, Orlik M (2005) Anisole as a solvent for organic electrochemistry. J Electroanal Chem 582: 165-170.

9. Venkatesan S, Chen Q, Ngo EC, Adhikari N, Nelson K, et al. (2014) Polyme solar cells processed using anisole as a relatively nontoxic solvent. Energy Technology 2: 269-274.

10. Trivedi MK, Patil S, Shettigar H, Bairwa K, Jana S (2015) Phenotypic and biotypic characterization of Klebsiella oxytoca: An impact of biofield treatment. J Microb Biochem Technol 7: 203-206.

11. Trivedi MK, Nayak G, Patil S, Tallapragada RM, Latiyal O, et al. (2015) An evaluation of biofield treatment on thermal, physical and structural properties of cadmium powder. J Thermodynamics Catal 6: 147.

12. Planck M (1903) Treatise on thermodynamics. (3rd edn), English translated by Alexander OGG, Longmans, Green, London, UK.

13. NIH (2008) National Center for Complementary and Alternative Medicine. CAM Basics. Publication 347.

14. Trivedi MK, Patil S, Shettigar H, Gangwar M, Jana S (2015) Antimicrobia sensitivity pattern of Pseudomonas fluorescens after biofield treatment. J Infect Dis Ther 3: 222.

15. Patil S, Nayak GB, Barve SS, Tembe RP, Khan RR (2012) Impact of biofield treatment on growth and anatomical characteristics of Pogostemon cablin (Benth.). Biotechnology 11: 154-162.

16. Nayak G, Altekar N (2015) Effect of biofield treatment on plant growth and adaptation. J Environ Health Sci 1: 1-9. 
Citation: Trivedi MK, Branton A, Trivedi D, Nayak G, Saikia G, et al. (2015) Thermal, Spectroscopic and Chemical Characterization of Biofield Energy Treated Anisole. Organic Chem Curr Res 4:152. doi:10.4172/2161-0401.1000152

Page 6 of 6

17. Shinde V Sances F, Patil S, Spence A (2012) Impact of biofield treatment on growth and yield of lettuce and tomato. Aust J Basic \& Appl Sci 6: 100-105.

18. http://www.pherobase.com/ms-popup.html?anisole

19. Rieley G (1994) Derivatization of organic-compounds prior to gaschromatographic combustion-isotope ratio mass-spectrometric analysis: Identification of isotope fractionation processes. Analyst 119: 915-919.

20. Smith BC (2011) Fundamentals of Fourier transform infrared spectroscopy, CRC Press, Taylor and Francis Group, Boka Raton, New York.
21. Gerrard DL, Maddams WF, Tucker PJ (1978) Solvent effects in U.V. absorption spectra. IV. substituted phenols, anisole and phenetole. Spectrochim Acta A: Mol Spectros 34: 1225-1230.

22. Balfour WJ, Ram SR (1982) The near-ultraviolet vapour phase absorption spectrum of anisole. Chem Phys Lett 92: 279-282.
Citation: Trivedi MK, Branton A, Trivedi D, Nayak G, Saikia G, et al (2015) Thermal, Spectroscopic and Chemical Characterization of Biofield Energy Treated Anisole. Organic Chem Curr Res 4:152. doi:10.4172/2161 0401.1000152
OMICS International: Publication Benefits \& Features

\section{Unique features:}

- Increased global visibility of articles through worldwide distribution and indexing

Showcasing recent research output in a timely and updated manner

Special issues on the current trends of scientific research

Special features:

- 700 Open Access Journals

50,000 Editorial team

Rapid review process

Quality and quick editorial, review and publication processing

Indexing at PubMed (partial), Scopus, EBSCO, Index Copernicus, Google Scholar etc.

Sharing Option: Social Networking Enabled

- Authors, Reviewers and Editors rewarded with online Scientific Credits

Better discount for your subsequent articles

Submit your manuscript at: http://www.omicsgroup.org/iournals/submission 